\title{
A Resistance to Systemic Symptom Expression of Melon Necrotic Spot Virus in Melon
}

\author{
Cristina Mallor, ${ }^{1}$ José María Álvarez, and Marisol Luis-Arteaga \\ Servicio de Investigación Agroalimentaria, D.G.A., Apdo. 727, 50080 Zaragoza, Spain
}

\begin{abstract}
AdDITIONAL INDEX woRDs. Cucumis melo L., disease resistance, MNSV, temperature effects, virus distribution
Abstract. Melon necrotic spot virus (MNSV) has been found affecting melon (Cucumis melo L.) crops. At present the only known resistance in melon is controlled by a single recessive gene, $n s v$. The presence of $n s v$ in a melon genotype has been correlated with the lack of necrotic lesions on the mechanically inoculated cotyledons. Thus, in a screening program for MNSV resistance, melon genotypes that developed necrotic lesions in the inoculated cotyledons were discarded. However, in this paper we show that some melon accessions mechanically inoculated with MNSV do develop local necrotic lesions, therefore showing the absence of the gene $n s v$, but fail to develop the systemic symptoms typical of diseased plants under the screening conditions. In some of these accessions the influence of the temperature on the development of systemic symptoms was studied. The results showed that, depending on the accession, temperatures under 25 or $20^{\circ} \mathrm{C}$ enhanced the systemic development of the disease. One of the tested varieties, 'Doublon', did not develop systemic symptom at any of the tested temperatures $\left(15,17.5,20,22.5,25,27.5\right.$, and $\left.30{ }^{\circ} \mathrm{C}\right)$. In this variety, the lack of systemic symptoms was correlated to the lack of virus infection of these tissues based upon ELISA results. MNSV was not detected in the uninoculated parts of the plant, and seems to remain confined to the local lesions produced on the cotyledons following the mechanical inoculation. Restriction of viral multiplication and/or cell-to-cell movement could explain the pattern of viral distribution in this variety. This reaction was observed in the 'Doublon' plants mechanically inoculated with each of five isolates of MNSV tested, including an isolate that overcomes the $n s v$ gene resistance.
\end{abstract}

Melon (Cucumis melo L.) is one of the most important cucurbit crops in tropical and temperate areas of the world. One of the viruses that affect melon is Melon necrotic spot virus, MNSV, which can cause important economic damage to protected crops. MNSV is a ssRNA isometric virus that belongs to the genus Carmovirus (family Tombusviridae). It is transmitted in nature by the soil fungus Olpidium bornovanus (Satiyanci) Karling (Campbell and Sim, 1994; Furuki, 1981) and by the cucumber beetles Diabrotica undecimpunctata undecimpunctata Mannh. and D. balteata Lec. (Coudriet et al., 1979). MNSV was first described by Kishi (1966) on melons in Japan, and later was reported infecting melons in France (Marrou and Risser, 1967), United States (Gonzalez-Garza et al., 1979), Greece (Avgelis, 1985), Sweden (Ryden and Person, 1986), Spain (Luis-Arteaga, 1986), and Italy (Tomassoli et al., 1999), cucumber (C. sativus L.) in The Netherlands (Bos et al., 1984), U.K. (Tomlinson and Thomas, 1986), and Greece (Avgelis, 1991), and watermelon (Citrullus vulgaris Schard) in Greece (Avgelis, 1989) and Spain (Cuadrado et al., 1993).

Symptoms caused by MNSV on melon plants may be observed in apical leaves as chlorotic spotting, which later develop into necrotic spotting. On stems and petioles, necrotic streaks frequently appear and then the entire plant may wilt. Plants that survive MNSV infection produce less than healthy ones (Avgelis, 1985).

One single recessive gene, $n s v$, has been reported to control the only resistance found to MNSV in melon. This gene is present in cvs. Gulfstream, PMR-5, and Planters Jumbo (Coudriet et al., 1981) and in 'PI 161375' (Maestro, 1992). This resistance has been reported to be effective against all assayed strains of the

Received for publication 4 Dec. 2002. Accepted for publication 20 Mar. 2003. We gratefully acknowledge the financial support provided by the projects GENRES 108 funded by the EU and INIA SC98-46-C3-1 funded by the Spanish Ministerio de Ciencia y Tecnología. We also thank the INIA for the first author's predoctora research grant, M. Aranda for kindly providing the isolate MNSV-264, and M.L. Gómez-Guillamón and E. Moriones for critical reading of the manuscript.

${ }^{1}$ To whom reprint request should be addressed; e-mail cmallor@aragob.es. virus (Coudriet et al., 1981; Gonzalez-Garza et al., 1979; Maestro, 1992; Pitrat and Lecoq, 1984). However, recently a MNSV strain that is able to overcome the $n s v$ controlled resistance has been reported (Díaz et al., 2002). Thus, the need of screening efforts to diversify the resistance genes available to control MNSV infections in melon is reinforced. When a plant was mechanically inoculated with MNSV in the cotyledons and no necrotic local lesion reaction was observed, it was resistant to MNSV and homozygous for the $n s v$ gene (Coudriet et al., 1981; Pitrat and Lecoq, 1984). Those plants that exhibited necrotic local lesions were rejected as sources of resistance to MNSV. However, after mechanical inoculation of a collection of lines and varieties of melon with MNSV, we observed some variability in the development of systemic symptoms in those plants that exhibited necrotic local lesions. In this paper, we studied genotypes that exhibited a symptomless systemic reaction after development of necrotic local lesions to assess if the lack of systemic symptoms could be correlated to the lack of virus infection of these tissues and if this trait could be used to control MNSV infections.

\section{Materials and Methods}

Plant material and virus strains. The different melon accessions used in this study as well as their geographical origin are shown in Table 1. MNSV isolates were: M-8-85, collected from melon crops in Almería area (southeastern Spain) during 1985, and MNSV-264, collected on melon plants with an $n s v / n s v$ genotype in Almería in 1999 (Díaz et al., 2002). To validate the results obtained with M-8-85 and MSNV-264 isolates, we used the following MNSV isolates: M-4-88 and M-1-90, both collected in Almería during 1988 and 1990, respectively, and M-8-93 collected in Zaragoza (northeastern Spain) during 1993, all of them from $\mathrm{Nsv}$ /- melon plants.

GERMPLASM INOCULATION WITH MNSV. Seeds were pregerminated at $30^{\circ} \mathrm{C}$ for $3 \mathrm{~d}$. Then, they were put into pots which were placed in a glasshouse at temperatures ranging from 18 to $25^{\circ} \mathrm{C}$. 
Table 1. Results of the mechanical inoculation of several melon accessions with the M-8-85 and MNSV-264 isolates of MNSV under greenhouse conditions; $\mathrm{R}=$ resistant, $\mathrm{S}=$ susceptible, according with the Pitrat and Lecoq (1984) criteria; $\mathrm{N}=$ number of inoculated plants.

\begin{tabular}{|c|c|c|c|c|c|c|c|c|c|}
\hline \multirow[b]{3}{*}{ Accession } & \multirow[b]{3}{*}{ Origin } & \multicolumn{4}{|c|}{ M-8-85 } & \multicolumn{4}{|c|}{ MNSV-264 } \\
\hline & & \multirow[b]{2}{*}{$\mathrm{N}$} & \multicolumn{2}{|c|}{ Symptoms } & \multirow[b]{2}{*}{ Reaction } & \multirow[b]{2}{*}{$\mathrm{N}$} & & & \\
\hline & & & Local & Systemic & & & Local & Systemic & Reaction \\
\hline 2624-BI & USDA (U.S.) & 9 & 9 & 1 & $\mathrm{~S}$ & 10 & 10 & 0 & $\mathrm{~S}$ \\
\hline 26929-ms3 & USDA (U.S.) & 10 & 10 & 1 & $\mathrm{~S}$ & 10 & 10 & 0 & $\mathrm{~S}$ \\
\hline 52.252 & Turkey & 9 & 9 & 5 & S & 8 & 8 & 2 & $\mathrm{~S}$ \\
\hline $7 A-1-2$ & Spain & 10 & 10 & 1 & S & & & & \\
\hline $8 / 85$ & Yugoslavia & 10 & 10 & 0 & S & 10 & 10 & 2 & $\mathrm{~S}$ \\
\hline 9120 & Selection (S.I.A.) & 10 & 10 & 0 & S & 10 & 10 & 0 & $\mathrm{~S}$ \\
\hline Agostizo & Jaén (Spain) & 18 & 18 & 1 & S & & & & $\mathrm{S}$ \\
\hline Agrestis & Unknown & 9 & 9 & 0 & S & 10 & 10 & 0 & $\mathrm{~S}$ \\
\hline Amarillo Alargado & Badajoz (Spain) & 12 & 12 & 0 & S & 10 & 10 & 1 & $\mathrm{~S}$ \\
\hline Amarillo Blanco Piñón & Granada (Spain) & 12 & 12 & 6 & S & 10 & 10 & 1 & $\mathrm{~S}$ \\
\hline Amarillo Cáscara Pinta & Cáceres (Spain) & 12 & 12 & 4 & S & & & & \\
\hline Amarillo Exportación & Valencia (Spain) & 8 & 8 & 2 & S & 10 & 10 & 0 & S \\
\hline Amarillo Oval Tardío & Commercial cultivar & 12 & 12 & 2 & S & 10 & 10 & 2 & S \\
\hline ANC-103 & Andalucía (Spain) & 9 & 9 & 4 & $S$ & & & & \\
\hline ANC-117 & Andalucía (Spain) & 11 & 11 & 1 & S & & & & \\
\hline ANC-13 & Andalucía (Spain) & 10 & 10 & 0 & S & 10 & 10 & 0 & $\mathrm{~S}$ \\
\hline ANC-138 & Andalucía (Spain) & 11 & 11 & 4 & S & & & & \\
\hline ANC-157 & Andalucía (Spain) & 8 & 8 & 7 & $S$ & & & & \\
\hline ANC-25 & Andalucía (Spain) & 11 & 11 & 2 & S & & & & \\
\hline ANC-32 & Andalucía (Spain) & 11 & 11 & 2 & S & & & & \\
\hline ANC-37 & Andalucía (Spain) & 12 & 12 & 0 & $\mathrm{~S}$ & & & & \\
\hline ANC-41 & Andalucía (Spain) & 10 & 10 & 9 & S & & & & \\
\hline ANC-42 & Andalucía (Spain) & 12 & 12 & 12 & S & 12 & 12 & 1 & $\mathrm{~S}$ \\
\hline ANC-44 & Andalucía (Spain) & 11 & 11 & 2 & $\mathrm{~S}$ & & & & \\
\hline ANC-45 & Andalucía (Spain) & 10 & 10 & 2 & S & & & & \\
\hline ANC-52 & Andalucía (Spain) & 11 & 11 & 2 & S & & & & \\
\hline ANC-64 & Andalucía (Spain) & 12 & 12 & 10 & S & & & & \\
\hline ANC-71 & Andalucía (Spain) & 10 & 10 & 0 & S & & & & \\
\hline ANC-9 & Andalucía (Spain) & 10 & 10 & 3 & S & & & & \\
\hline ANC-93 & Andalucía (Spain) & 10 & 10 & 9 & S & & & & \\
\hline Banda de Godoy & Badajoz (Spain) & 10 & 10 & 5 & S & 10 & 10 & 4 & S \\
\hline Baza & Granada (Spain) & 12 & 12 & 0 & S & 10 & 10 & 0 & S \\
\hline Bolas & Toledo (Spain) & 12 & 12 & 3 & S & 9 & 9 & 1 & S \\
\hline Caña Dulce & Jaén (Spain) & 12 & 12 & 5 & S & & & & \\
\hline Casero Rayado & Salamanca (Spain) & 12 & 12 & 10 & S & & & & \\
\hline Castellanos & Córdoba (Spain) & 9 & 9 & 4 & $S$ & & & & \\
\hline CC140884-1C & Cáceres (Spain) & 8 & 8 & 2 & S & & & & \\
\hline CC-17 & Cataluña (Spain) & 10 & 10 & 0 & S & & & & \\
\hline $\mathrm{CC}-21$ & Cataluña (Spain) & 11 & 11 & 0 & $S$ & & & & \\
\hline Común & Teruel (Spain) & 12 & 12 & 3 & S & & & & \\
\hline CUM 122 & Tunisia & 10 & 10 & 4 & S & & & & \\
\hline CUM 170 & Russia & 10 & 10 & 5 & S & & & & \\
\hline CUM 172 & Georgia & 9 & 9 & 1 & S & & & & \\
\hline CUM 204 & Unknown & 10 & 10 & 9 & S & & & & \\
\hline CUM 230 & Hungary & 10 & 10 & 7 & S & & & & \\
\hline CUM 241 & Russia & 10 & 10 & 0 & S & & & & \\
\hline CUM 263 & Mongolia & 10 & 10 & 5 & S & & & & \\
\hline CUM 299 & Italy & 10 & 10 & 7 & S & & & & \\
\hline CUM 31 & Germany & 10 & 10 & 4 & S & & & & \\
\hline CUM 333 & Turkey & 10 & 10 & 5 & S & & & & \\
\hline CUM 334 & Turkey & 10 & 10 & 5 & S & & & & \\
\hline CUM 335 & USA & 9 & 9 & 4 & S & & & & \\
\hline CUM 338 & Mongolia & 10 & 10 & 6 & S & & & & \\
\hline CUM 355 & Irak & 10 & 10 & 8 & S & & & & \\
\hline CUM 363 & Italy & 10 & 10 & 0 & S & & & & \\
\hline CUM 366 & Russia & 7 & 7 & 0 & S & & & & \\
\hline CUM 372 & Italia & 10 & 10 & 10 & S & & & & \\
\hline CUM 375 & Georgia & 8 & 8 & 3 & S & & & & \\
\hline CUM 376 & Georgia & 9 & 9 & 1 & S & & & & \\
\hline CUM 378 & Georgia & 10 & 10 & 3 & S & & & & \\
\hline CUM 379 & Georgia & 10 & 10 & 8 & S & & & & \\
\hline CUM 443 & Canada & 10 & 10 & 9 & S & & & & \\
\hline CUM 468 & USA & 9 & 9 & 0 & S & & & & \\
\hline CUM 474 & USA & 9 & 9 & 6 & S & & & & \\
\hline CUM 479 & USA & 10 & 10 & 2 & S & & & & \\
\hline CUM 481 & Albania & 9 & 9 & 9 & S & & & & \\
\hline CUM 483 & Italy & 10 & 10 & 7 & S & & & & \\
\hline CUM 484 & Italy & 8 & 8 & 8 & S & & & & \\
\hline CUM 496 & Croatia & 10 & 10 & 1 & S & & & & \\
\hline CUM 85 & Greece & 9 & 9 & 9 & S & & & & \\
\hline
\end{tabular}




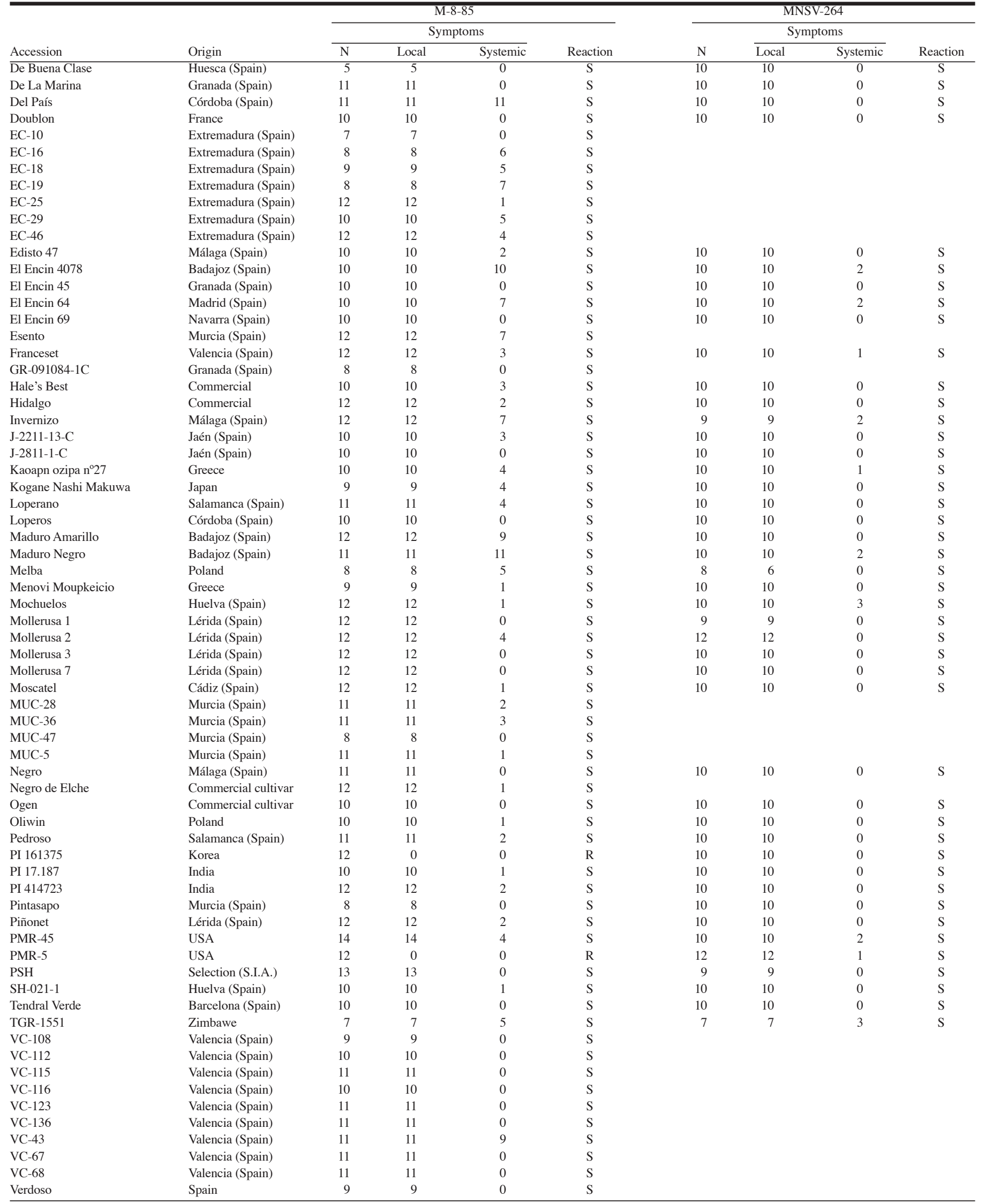


Table 2. Reaction of different melon accessions after mechanical inoculation with the M-8-85 isolate of MNSV and incubation at 20, 25 or $30^{\circ} \mathrm{C}$. The results are expressed as number of plants showing systemic symptoms / total number of plants tested.

\begin{tabular}{lccc}
\hline & \multicolumn{3}{c}{ Temp $\left({ }^{\circ} \mathrm{C}\right)$} \\
\cline { 2 - 4 } Accessions & 20 & 25 & 30 \\
\hline 8 -85 & $3 / 10$ & $3 / 9$ & $0 / 9$ \\
9120 & $5 / 9$ & $4 / 9$ & $0 / 10$ \\
Agrestis & $0 / 6$ & $0 / 11$ & $0 / 9$ \\
ANC-42 & $12 / 12$ & $1 / 12$ & $0 / 10$ \\
De la marina & $1 / 11$ & $1 / 9$ & $0 / 10$ \\
Doublon & $0 / 10$ & $0 / 10$ & $0 / 10$ \\
El Encín 45 & $0 / 12$ & $0 / 10$ & $0 / 10$ \\
El Encín 69 & $0 / 12$ & $0 / 9$ & $0 / 10$ \\
Invernizo & $4 / 10$ & $0 / 10$ & $0 / 10$ \\
Mollerusa 1 & $1 / 10$ & $0 / 10$ & $0 / 10$ \\
Mollerusa 3 & $2 / 12$ & $0 / 10$ & $0 / 11$ \\
Negro & $8 / 10$ & $2 / 10$ & $0 / 10$ \\
PMR-5 & $0 / 10$ & $0 / 10$ & $0 / 10$ \\
\hline
\end{tabular}

When seedlings reached the two cotyledons growth stage, severa plants of each line or variety were mechanically inoculated with the MNSV isolates.

For mechanical inoculation of test plants, $1 \mathrm{~g}$ of inoculated melon cotyledons exhibiting necrotic local lesions was harvested 4 or $5 \mathrm{~d}$ after inoculation and ground with $4 \mathrm{~mL}$ of $0.03 \mathrm{M} \mathrm{Na}_{2} \mathrm{HPO}_{4}$ solution containing $0.2 \%$ sodium diethyldithiocarbamate. The extracted juice was mixed with 400 -mesh carborundum $(0.375$ $\left.\mathrm{g} \cdot \mathrm{mL}^{-2}\right)$ and activated charcoal $\left(0.375 \mathrm{~g} \cdot \mathrm{mL}^{-1}\right)$ and then was rubbed on the cotyledons of 7- to 10-d-old seedlings.

VIRUS DETECTION. MNSV detection was performed by means of a double-antibody sandwich-enzyme linked immunosorbert assay (DAS-ELISA) technique (Clark and Adams, 1977), using a commercial polyclonal MNSV antisera (Loewe Phytodiagnostica, Otterfing, Germany). ELISA tests were performed following the manufacturer's recommendation. The procedure was carried out in polystyrene plates using $100 \mu \mathrm{L}$ per well of each of the solutions, antigen, IgGs, alkaline phosphatase-conjugated IgGs and substrate solution. Tissue samples (a maximum of $0.3 \mathrm{~g}$ ) were ground in ELISA extraction buffer at 1/10 (w/v) dilution. The absorbance $(405 \mathrm{~nm})$ was measured with a Titertek Multiskan Plus (Labsystems, Finland) spectrophotometer. Samples were considered as positive when their absorbance values exceeded three times the values observed in healthy plants used as negative controls.

TeMPERATURE EFFECTS. The germplasm inoculation with MNSV in a glasshouse revealed that for some accessions, although necrotic local lesions were observed in the cotyledons systemic symptoms were not observed consistently (Table 1).

Nine of these accessions (Table 2) were selected because they did not show systemic symptoms when inoculated either during spring or during autumn, when the environmental conditions were the most suitable for systemic symptoms development. These accessions were inoculated with the M-8-85 isolate and were grown in a growth chamber either at 20,25 or $30{ }^{\circ} \mathrm{C}, 60 \% \mathrm{RH}$ and $14 \mathrm{~h}$ photoperiod $\left(300 \mu \mathrm{mol} \cdot \mathrm{m}^{-2} \cdot \mathrm{s}^{-1}\right)$. As test plants, we used varieties with differential reaction to M-8-85 inoculation under greenhouse conditions: 'PMR-5' carrying the nsv gene, 'Doublon' which did not show any systemic symptoms, 'Invernizo' showing systemic symptoms on approximately $50 \%$ of the inoculated plants and 'ANC-42' which developed systemic symptoms on all inoculated plants at $20{ }^{\circ} \mathrm{C}$ (Table 1). In another experiment, 10 plants of each of those varieties were inoculated with the MNSV isolate M-8-85 and maintained in growth chambers at $15,17.5$, $20,22.5,25,27.5$, and $30^{\circ} \mathrm{C}$ (at conditions mentioned above). Plants were observed during $30 \mathrm{~d}$, and presence or absence of local and systemic symptoms were recorded.

DyNAMic OF VIRUS INFECTION. A total of 24 plants of each of the varieties 'Doublon', 'ANC-42', and 'PMR-5' were studied. Sowings were done at different days, in a way that allow us to inoculate six plants per variety at the right inoculation stage (two cotyledons) each $3 \mathrm{~d}$. We used the MNSV isolate M-8-85 and the inoculated plants were divided into two groups and maintained in two growth chambers at 20 or $27.5^{\circ} \mathrm{C}$ (at conditions mentioned above). Three days after the last inoculation, the roots, hypocotyl, cotyledons, and apical leaves of each plant were analyzed for MNSV presence by ELISA. As controls, 10 plants from each variety that were not inoculated were used.

ANALYSIS OF LOCAL INFECTION. Thirty plants of each of the accessions 'Doublon', 'PMR-5' and 'Maduro Negro' (susceptible control developing systemic symptoms) were kept in a growth chamber at $20{ }^{\circ} \mathrm{C}$ (at conditions mentioned above). At the two cotyledons growth stage, 10 and 20 plants of each accession were inoculated with the isolates M-8-85 and MNSV-264 respectively. Eight days after the inoculation, samples of each plant were collected from the following parts: local lesions (A1) (if present), cotyledonar tissue between local lesions (A2), and uninoculated apical leaves (A3). Presence of MNSV in the collected and in equivalent samples from uninoculated controls was analyzed by ELISA (see before).

\section{Results}

RESPONSE OF INOCULATED MELON GERMPLASM. The results of the inoculations performed in this study are summarized in Table 1. According to Pitrat and Lecoq (1984) criteria, only the accessions 'PI 161375' and 'PMR-5' did not develop necrotic local lesions on inoculated cotyledons and therefore were resistant to the isolate M-8-85 of MNSV, whereas none of the accessions tested were resistant to isolate MNSV-264. However, some variability in the development of systemic symptoms on inoculated plants could be observed. Thus, 41 of the 138 accessions that exhibited necrotic local lesions on cotyledons when inoculated with the M8-85 isolate did not show any systemic symptom and the same behavior was observed in 41 of the 60 accessions inoculated with the MNSV-264 isolate. In general, MNSV-264 was less efficient in inducing systemic symptoms on mechanically inoculated plants than M-8-85, as shown in Table 1. Local symptoms consisted in small necrotic lesions that appeared on inoculated cotyledons $\approx 4$ $\mathrm{d}$ after inoculation. When present, systemic symptoms consisted of foliar mosaic with small chlorotic spots that become necrotic

Table 3. Number of plants showing systemic symptoms after inoculation of 10 plants of different varieties of melon with the MNSV isolate $\mathrm{M}-8-85$, and incubation at different temperatures.

\begin{tabular}{lcccc}
\hline \multirow{2}{*}{$\begin{array}{l}\text { Temp } \\
\left({ }^{\circ} \mathrm{C}\right)\end{array}$} & Invernizo & ANC-42 & Doublon & PMR-5 \\
\cline { 2 - 5 } 30 & 0 & 0 & 0 & 0 \\
27.5 & 0 & 0 & 0 & 0 \\
25 & 0 & 1 & 0 & 0 \\
22.5 & 0 & 6 & 0 & 0 \\
20 & 4 & 10 & 0 & 0 \\
17.5 & 7 & All died & 0 & 0 \\
15 & All died & All died & 0 & 0 \\
\hline
\end{tabular}


Table 4. Reaction of 'ANC-42', 'Doublon' and 'PMR-5' plants after mechanical inoculation of ten plants per variety with several MNSV isolates and incubated at $20^{\circ} \mathrm{C}$.

\begin{tabular}{lccc}
\hline & \multicolumn{3}{c}{ Variety } \\
\cline { 2 - 4 } Isolate & ANC-42 & Doublon & PMR-5 \\
\hline M-8-85 & LL, SS & LL & 0 \\
M-1-90 & LL, SS & LL & 0 \\
M-4-88 & LL, SS & LL & 0 \\
M-8-93 & LL, SS & LL & 0 \\
MNSV-264 & LL (SS) & LL & LL (SS) \\
\hline
\end{tabular}

${ }^{\mathrm{z} L L}=$ local necrotic lesions; $\mathrm{SS}=$ systemic symptoms. Brackets indicate that symptoms were not observed in all inoculated plants.

\section{'ANC-42'}

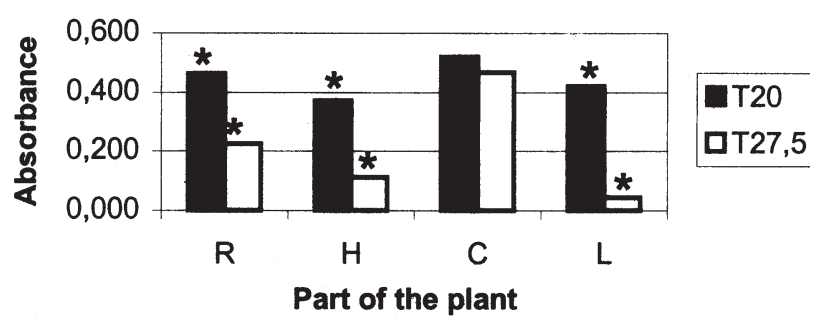

\section{'Doublon'}

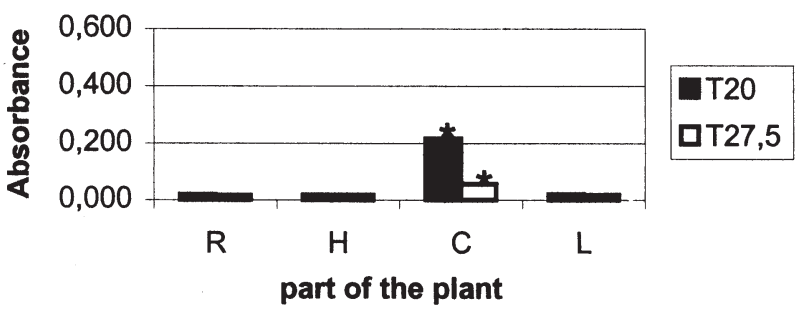

'PMR-5'

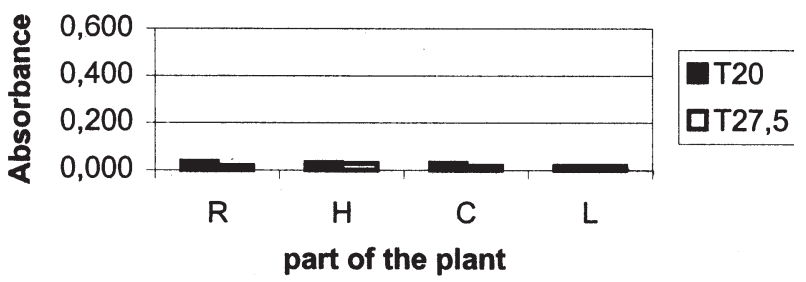

Fig. 1. MNSV accumulation after mechanical inoculation with isolate M-8-85, measured as absorbance at $405 \mathrm{~nm}$ in DAS-ELISA analysis, in four parts of the plant $(\mathrm{R}=$ root, $\mathrm{H}=$ hypocotyl, $\mathrm{C}=$ cotyledon, $\mathrm{L}=$ leaf $)$ in three melon lines ('ANC-42', 'Doublon', and 'PMR-5') grown in growth chambers at two temperatures $\left(20\right.$ and $\left.27.5^{\circ} \mathrm{C}\right)$. The bars show the mean absorbance of three plants. * on the bars means indicate that significant differences occur between the absorbances at the two temperatures tested (Student's $t$ test, 0.05).

a few days after appearance, and necrotic streaks along the stems and petioles.

Temperature AND ISOlate EFFECTS. Ten accessions that do not develop systemic symptoms in greenhouse conditions were mechanically inoculated at different temperatures $(20,25$, and 30 $\left.{ }^{\circ} \mathrm{C}\right)$. The results showed that in six of these accessions some plants developed systemic symptoms, mainly at the lowest temperature tested of $20{ }^{\circ} \mathrm{C}$, whereas 'Agrestis', 'Doublon', 'El Encin 45' and 'El Encin 69' never developed systemic symptoms (Table 2). More accurate experiments indicated a temperature dependence of systemic symptoms development. Thus, on 'ANC-42' temperatures under $25^{\circ} \mathrm{C}$ enhanced systemic symptom development and below $20{ }^{\circ} \mathrm{C}$ plants started wilting and finally died, in some of them without previous exhibition of systemic symptom typical of MNSV infection (Table 3). On 'Invernizo', systemic symptoms appeared only when temperatures were under $20^{\circ} \mathrm{C}$, and plants wilting occurred under $17.5^{\circ} \mathrm{C}$ (Table 3). When the plants started wilting positive ELISA tests indicated the presence of MNSV in all cases. Interestingly, 'PMR-5' showed neither local nor systemic symptoms and 'Doublon' did not show systemic symptoms at any of the temperatures tested (Table 3). This two varieties were inoculated with five MNSV isolates at $20^{\circ} \mathrm{C}$, using 'ANC-42' as inoculation control. All plants of 'ANC-42' developed necrotic local lesions and systemic symptoms, appeared in all of them except with MNSV-264. 'Doublon' plants developed only local symptoms and 'PMR-5' did not react with any of the MNSV isolates used except with MNSV-264, that induced local necrotic lesions in the inoculated cotyledons (Table 4). Similar to 'ANC-42', only a few plants of 'PMR-5' developed systemic symptoms when inoculated with MNSV-264.

VIRUS ACCUMULATION IN DIFFERENT PARTS OF THE PLANT. Virus accumulation in different parts of the plant, based on absorbance values obtained in ELISA tests, was influenced by variety and temperature (Fig. 1). In the susceptible 'ANC-42', MNSV was detected in all parts of the plant and higher virus accumulation occurred at $20^{\circ} \mathrm{C}$ except in the cotyledons. However, no virus was detected in any part of the plants of 'PMR-5'. In 'Doublon', MNSV was only detected in cotyledons (inoculated area), but no MNSV was detected in the roots, hypocotyl or leaves. Concentration of MNSV in the cotyledons of 'Doublon' was significantly higher at $20{ }^{\circ} \mathrm{C}$ than at $27.5^{\circ} \mathrm{C}$, although lower than in the equivalent part of 'ANC-42'.

VIRUS ACCUMULATION IN NECROTIC LOCAL LESION AND ADJACENT TISSUES. When the M-8-85 MNSV isolate was inoculated (Fig. 2), the virus was found in the local lesions, cotyledon tissue between lesions, and uninoculated leaves of all plants of the susceptible variety tested ('Maduro Negro'), the concentration of the virus was highest in the necrotic local lesions (A1), intermediate in the area between lesions (A2), and lowest in the uninoculated leaves (A3). Nevertheless, in 'Doublon' plants, the virus was only de-

Fig. 2. MNSV accumulation, after mechanical inoculation with isolate M-8-85, measured as absorbance at $405 \mathrm{~nm}$ in DAS-ELISA analysis, in A1 = local lesions, $\mathrm{A} 2$ = area between lesions, $\mathrm{A} 3=$ uninoculated leaves, of three melon lines ('Maduro Negro', 'Doublon' and 'PMR-5') grown at $20^{\circ} \mathrm{C}$. The bars show the mean absorbance value of 10 plants exhibiting similar symptoms.

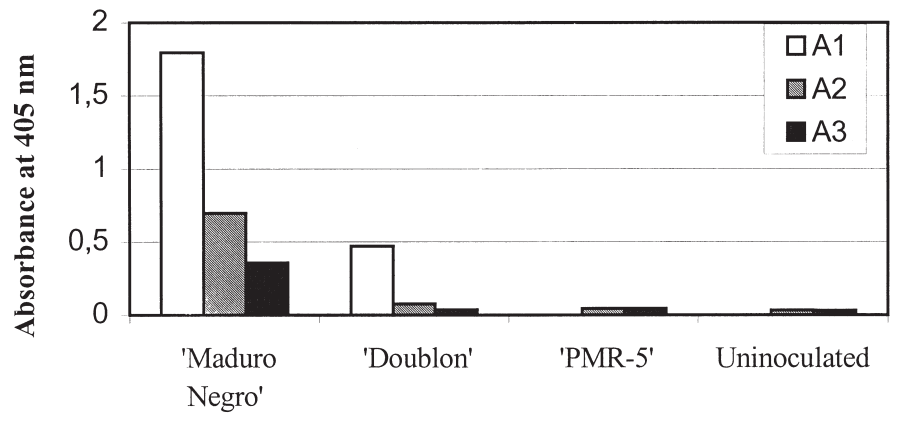




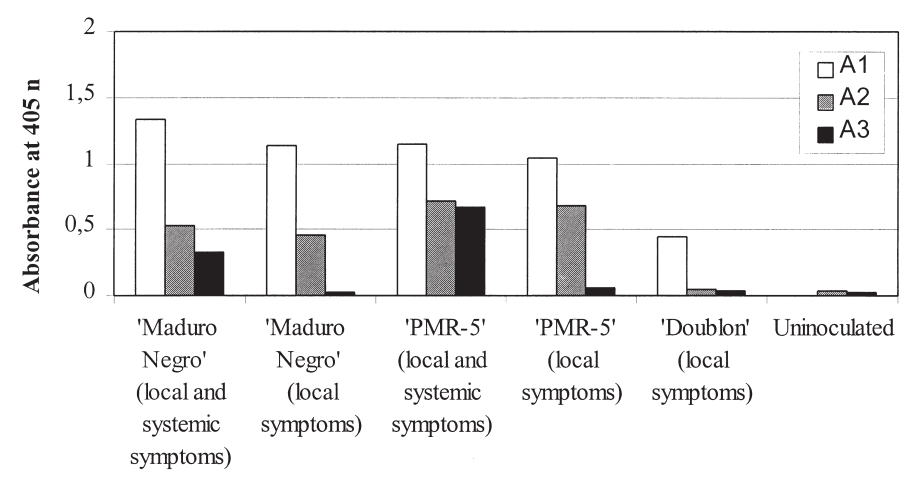

Fig. 3. MNSV accumulation, after mechanical inoculation with isolate MNSV264, measured as absorbance at $405 \mathrm{~nm}$ in DAS-ELISA analysis, in A1 = loca lesions, $\mathrm{A} 2=$ area between lesions, $\mathrm{A} 3$ = uninoculated leaves, of plants of three melon lines ('Maduro Negro', 'Doublon' and 'PMR-5') grown at $20^{\circ} \mathrm{C}$ The bars show the mean absorbance value of all the plants exhibiting similar symptoms among twenty plants tested.

zLocal and systemic symptoms $=1$ plant.

Local symptoms $=19$ plants.

$\times$ Local and systemic symptoms $=8$ plants

${ }^{\mathrm{L}}$ Local symptoms $=12$ plants.

Local symptoms $=20$ plants

tected in the necrotic lesions, although at lower levels than in the susceptible control, and no virus was detected in the area between lesions, nor in the uninoculated leaves. In 'PMR-5', similar to the uninoculated control, no virus was detected in any tissue. With the MNSV-264 isolate (Fig. 3), only one of the 20 inoculated plants of 'Maduro Negro' exhibited systemic symptoms and MNSV was detected in every tissue tested; the remaining plants showed only necrotic local lesions and MNSV was detected in the inoculated tissues but not in the uninoculated parts of the plants (Fig. 3). All the plants of 'PMR-5' developed necrotic local lesions and eight of the 20 inoculated plants developed systemic symptoms consisting of chloro-necrotic spots on uninoculated leaves; the virus was detected in all analyzed parts of these plants and in the A1 and A2 tissues of the remaining plants. Similar to 'PMR5', all plants of 'Doublon' developed necrotic local lesions but MNSV was only detected in the necrotic lesions (A1). As shown before, systemic symptoms were never observed in this variety and no virus was detected in uninoculated tissues (Fig. 3). In all the genotypes tested the maximum virus accumulation occurred in the tissue of necrotic lesion, with the highest levels detected in 'PMR-5' and the lowest in 'Doublon'.

\section{Discussion}

When screening Cucumis melo germplasm for resistance to MNSV, we observed that several accessions failed to develop systemic symptoms although they developed necrotic local lesions in the inoculated cotyledons and therefore should have been discarded as resistant following the criteria for the $n s v$ gene (Coudriet et al., 1981; Pitrat and Lecoq, 1984). Under natural infections, a high variability in symptoms induced by MNSV and differences according to the growing seasons have been reported, suggesting that the disease expression may be affected by environmental conditions (Juárez et al., 1994; Lecoq and Pitrat, 1982). Since we screened the plants under glasshouse conditions, the absence of systemic symptoms could have been caused by unsuitable environmental conditions for symptoms development. Therefore, some of these varieties were tested under controlled conditions and the results indicated a temperature dependence for systemic symptoms development in some of them (Table 2). Thus, temperatures under $25^{\circ} \mathrm{C}$ for ' ANC- 42 ' and under $20^{\circ} \mathrm{C}$ for 'Invernizo' enhanced systemic development of the disease caused by MNSV. So, in most cases the absence of systemic symptoms development may be due to unfavorable environmental testing conditions for symptoms expression. These results agreed with the observations of Lecoq and Pitrat (1982) that MNSV symptoms may not appear in all plants if the environmental conditions are not adequate, appearance being generally favored by low temperatures. Additionally, we also observed that variability in the development of systemic symptoms can occur depending on the inoculated MNSV isolate. Thus, comparing isolates M-8-85 and MNSV-264, generally a larger number of plants showed systemic symptoms when inoculated with M-8-85, which induced similar or more severe symptoms than when inoculated with MNSV-264. This may be due to the fact that resistance-breaking strains, like MNSV-264, can be less fit in other attributes necessary for spread or persistence (Hammond, 1998).

The reaction of 'Doublon' differed from that of the other accessions. This variety, although exhibiting necrotic local lesions in the inoculated cotyledons never showed systemic symptom at any of the temperatures tested, including those below $20^{\circ} \mathrm{C}$ that appeared to be the most suitable for MNSV systemic symptom development.

Following the criteria for the nsv gene, 'Doublon', similar to 'ANC-42' and 'Maduro Negro', should be discarded as not carrying the gene because all plants showed local lesions after mechanical inoculation with all MNSV isolates and temperatures tested. In contrast, other varieties, such as 'PMR-5', did not develop local lesions and therefore are considered to carry the $n s v$ resistance gene following the same criteria. The latter, confirmed as MNSV-264, a MNSV isolate reported to overcome the $n s v$ gene resistance (Diaz et al., 2002), was able to infect 'PMR-5'. 'Doublon' although developing necrotic local lesions in the inoculated cotyledons appeared to behave differently than the other susceptible varieties such as 'ANC-42' and 'Maduro Negro'. We never observed the development of systemic symptoms nor detected MNSV in noninoculated parts of this variety at any of the conditions tested. This suggested the presence of a resistance trait in 'Doublon' different from that provided by the $n s v$ gene. In this variety, MNSV was only detected in the necrotic local lesions that appeared after mechanical inoculation (Figs. 1 to 3). However, the level of the virus in the lesions was lower than in susceptible controls (Figs. 2 and 3), probably indicating some restriction to virus replication and/or cell-to-cell spread in initially infected tissues of 'Doublon'. This reaction resembles the hypersensitive resistance response to TMV controlled by the $N$ ' gene in tobacco that determines inhibition of multiplication of the avirulent strain (Fraser, 1992). The existence of some restriction of cell-to-cell spread in 'Doublon', is also supported by the nondetection of MNSV outside the necrotic local lesion. Atabekov and Dorokhov (1984) suggested that as observed here, resistance of plants to viruses can result from the inhibition of the virus transport from infected to healthy cells. After initial infection viruses need to spread locally, from cell-to-cell through plasmodesmata and then distantly through the vascular system (Hull, 1989). In 'Doublon', the resistance to systemic infection may be the result of restriction of cell-to-cell movement, as reported in other incompatible virus-plant interactions, such as with barley stripe mosaic virus (BSMV) in oat plants (Zhen and Edwards, 1990), turnip crinkle virus (TCV) in Arabidopsis thaliana ecotype Dijon (Simon et al., 1992) or subterranean clover mottle virus (SCMoV) in highly 
resistant cultivars of subterranean clover (Njeru et al., 1995). Nevertheless, our results do not allow us to discard the existence of some restriction to virus replication or long-distance transport. Therefore, these aspects should be further studied.

We conclude therefore that a novel resistance mechanism to MNSV infection is present in 'Doublon'. It is interesting that this resistance is also effective against MNSV isolates that overcome the only reported resistance to MNSV conferred by the $n s v$ gene, such as MNSV-264. Studies are in progress to determine the genetic control of this resistance as well as its behavior when inoculation is performed using the natural vector of MNSV, the fungus $O$. bornovanus. Preliminary results (data not shown) indicated that when 'Doublon' plants were inoculated with $O$. bornovanus, MNSV was only detected on the roots and on the base of the hypocotyl, and no virus could be recovered from any aerial part of the plants.

\section{Literature Cited}

Atabekov,J.G. and Y.L. Dorokhov. 1984. Plant virus-specific transport function and resistance of plant to viruses. Adv. Virus Res. 29:313-364.

Avgelis, A. 1985. Occurrence of melon necrotic spot virus in Crete (Greece). Phytopathologische Zeitschrift 114:365-372.

Avgelis, A. 1989. Watermelon necrosis caused by a strain of melon necrotic spot virus. Plant Pathol. 38:618-622.

Avgelis, A. 1991. Melon necrotic spot virus in plastic houses on the island of Crete. Acta Hort. 287:349-354.

Bos, L., H.J.M. Van-Dorst, H. Huttinga, and D.Z. Maat. 1984. Further characterization of melon necrotic spot virus causing severe disease in glasshouse cucumbers in the Netherlands and its control. Neth. J. Plant Pathol. 90:55-69.

Campbell, R.N. and S.T. Sim. 1994. Host specificity and nomenclature of Olpidium bornovanus (= Olpidium radicale) and comparisons of Olpidium brassicae. Can. J. Bot. 72:1136-1143.

Clark, M.F. and A.N. Adams. 1977. Characteristics of the microplate method of enzyme-linked immunosorbent assay for the detection of plant viruses. J. Gen. Virol. 34:475-483.

Coudriet, D.L., A.N. Kishaba, and I.E. Carrol. 1979. Transmission of melon necrotic spot virus in muskmelons by cucumber beetles. J. Econ Entomol. 72:560-561.

Coudriet, D.L., A.N. Kishaba, and G.W. Bohn. 1981. Inheritance of resistance to muskmelon necrotic spot virus in a melon aphid-resistant breeding line of muskmelon. J. Amer. Soc. Hort. Sci. 106:789-791.

Cuadrado, I.M., J. Gómez, and P. Moreno. 1993. El virus de las manchas necróticas del melón (MNSV) en Almería. I. Importancia del MNSV como causa de la muerte súbita del melón. Boletín de Sanidad Vegetal. Plagas 19:93-106.

Díaz, J.A., C. Nieto, E. Moriones, and M.A. Aranda. 2002. Spanish melon necrotic spot virus isolate overcomes the resistance conferred by the recessive $n s v$ gene of melon. Plant Dis. 86:694.

Fraser, R.S.S. 1992. The genetics of plant-virus interactions: Implications for plant breeding. Euphytica 63:175-185.

Furuki,I. 1981. Epidemiological studies on melon necrotic spot. Shixuoka (Japan) Agr. Expt. Sta. Tech. Bul. 14.

González-Garza, R., D.J. Gumpf, A.M. Kishaba, and G.W. Bohn. 1979. Identification, seed transmission, and host range pathogenicity of a California isolate of melon necrotic spot virus. Phytopathology 69:340-345.

Hammond, R.W. 1998. Resistance to plant viruses:Anoverview, p. 163-171. In: A. Hadidi, R.K. Khetarpal, and H. Koganezawa (eds.). Plant virus disease control. Amer. Phytopathol. Soc., Madison, Wis.

Hull, R. 1989. The movement of viruses in plants. Annu. Rev. Phytopathol. 27:213-240.

Juárez, M.,A. Ortega, and C. Jordá. 1994. Variabilidad del virus del cribado. Hortofruticultura 11:37-40.

Kishi, K. 1966. Necrotic spot of melon, a new virus disease. Ann. Phytopath. Soc. Jpn. 32:138-144.

Lecoq, H. and M. Pitrat. 1982. Note sur les virus des cucurbitacees presents en France. Inst, National de la Recherche Agronomique, Centre de Recherches Agronomiques d'Avignon-Montfavet.

Luis-Arteaga, M. 1986. Virosis de Cucurbitáceas. I Jornadas Nacionales de Cultivos Protegidos. Almería (España). 14-17 May.

Maestro, C. 1992. Résistance du melon aux virus. Interaction avec les pucerons vecteurs. Analyse génétique sur des lignées haplodiploides. Thèse Docteur Sciences Université d'Aix-Marseille.

Marrou, J. and G. Risser. 1967. La criblure du melon: étude preliminaire d'une nouvelle maladie à virus du melon en culture sous serre. Annales des Épiphyties 18:193-203.

Njeru, R., R.A.C. Jones, K. Sivisathamparam, and M.G.K. Jones. 1995. Resistance to subterranean clover mottle virus in subterranean clover results from restricted cell-to-cell movement. Austral. J. Agr. Res. 46: 633-643.

Pitrat, M. and H. Lecoq. 1984. A rapid method to test muskmelons for several virus resistances. EUCARPIA. Cucumis and melon's 84 IIIrd Meeting, Plovdiv (Bulgaria), 2-5 July, p. 104-107.

Ryden, K. and P. Person. 1986. Melon necrotic spot-A new virus disease in Sweden. Vaxtskyddsnotiser 50:130-132.

Simon, A.E., X.H. Li, J.E. Lew, R. Stange, C.X. Zhang, M. Polacco, and C.D. Carpenter. 1992. Susceptibility of resistance of Arabidopsis thaliana to turnip crinkle virus. Mol. Plant Microbe Interact. 5:496-503.

Tomassoli, L., G. Siddu, A. Carta, G. Di-Lernia, and M. Barba. 1999 Infezione da 'melon necrotic spot virus' su melone in Sardegna. Informatore Fitopatologico 10:39-41.

Tomlinson, J.A. and B.J. Thomas. 1986. Studies on melon necrotic spot virus disease of cucumber and on the control of the fungus vector $(\mathrm{Ol}$ pidium radicale). Ann. Appl. Biol. 108:71-80.

Zhen, Y. and M.C. Edwards. 1990. Expression of resistance to barley stripe mosaic virus in barley and oat protoplast. J. Gen. Virol. 71: $1865-1868$. 